\title{
$\beta 2$ adrenergic agonist attenuates house dust mite-induced allergic airway inflammation through dendritic cells
}

\author{
Go Kato ${ }^{1}$, Koichiro Takahashi ${ }^{1 *}$, Hiroki Tashiro ${ }^{1}$, Keigo Kurata ${ }^{2}$, Hideharu Shirai ${ }^{2}$, Shinya Kimura ${ }^{1}$ \\ and Shinichiro Hayashi ${ }^{1}$
}

\begin{abstract}
Background: Long-acting $\beta 2$ adrenergic agonists ( $\angle A B A s)$ are commonly used combined with inhaled corticosteroids (ICS) to treat asthmatic patients. Previous reports suggest that LABAs have an anti-inflammatory effect in bronchial asthma, and this should be further investigated. The aim of this study was to investigate whether LABAs inhibit allergic airway inflammation and how this occurs.

Results: We assessed the effect of the LABA formoterol (FORM) on inflammatory cell responses in airway, lung and regional lymph nodes, using an HDM-induced murine allergic asthma model in vivo. The effect of FORM on cytokine production from bone marrow derived dendritic cells (BMDCs) stimulated with HDM was evaluated in vitro. Adoptive transfer of BMDCs pulsed with HDM in the presence or absence of FORM to naïve mice was performed and the inflammatory response to subsequent HDM challenge was analyzed. FORM treatment suppressed HDM-induced changes and caused an increase in the number of eosinophils and neutrophils in bronchoalveolar lavage. The concentration of IL-4 and IL-17 in lung tissue homogenate was elevated and led to an accumulation of IL-4, IL-13, IL-5 and IL-17 producing cells in regional lymph nodes. FORM inhibited the production of IL-6 and IL-23 from BMDCs stimulated with HDM in vitro, and enhanced IL-10 production. The BMDCs adoptive transfer experiment indicated that dendritic cells mediate the effect of FORM, since FORM treatment of BMDCs in vitro attenuated airway inflammation.

Conclusion: These results suggested that FORM modulates dendritic cell function and attenuates Th2 and Th17 responses induced by HDM. Thus, we propose that the clinical significance of LABAs should be re-investigated taking into account these immune-modulating effects.
\end{abstract}

Keywords: Bronchial asthma, $\beta 2$ adrenergic agonist, House dust mite, Dendritic cells

\section{Background}

Bronchial asthma is a chronic airway inflammation associated with inhaled allergens including those produced by house dust mites (HDM) [1,2], and other environmental materials [3]. The pathophysiology of bronchial asthma is characterized by bronchoconstriction, airway hyper-responsiveness, and airway remodeling [4-6]. Although airway eosinophilia is a hallmark of bronchial asthma, the inflammatory process is mediated mainly by Th2 type lymphocytes $[7,8]$. Recently, evidence has been

\footnotetext{
* Correspondence: takahak@cc.saga-u.ac.jp

'Division of Hematology, Respiratory Medicine and Oncology, Department of Internal Medicine, Faculty of Medicine, Saga University, 5-1-1 Nabeshima, Saga 849-8501, Japan

Full list of author information is available at the end of the article
}

accumulating that Th17 lymphocytes and their products, such as interleukin-17 (IL-17), mediate neutrophilic inflammation which plays an important role in severe asthma $[9,10]$.

Dendritic cells (DCs) are responsible for the initial antigen-induced immune response, as they act as antigen presenting cells (APC) [11]. In the airways, DCs are present in the subepithelial region and process and present exogenous antigens. Naïve $T$ cells recognize the antigen presented on DCs and differentiate into helper $\mathrm{T}$ cells $[12,13]$. Cytokines produced from DCs determine the direction of helper $\mathrm{T}$ cell differentiation and regulate characteristics of the inflammatory response [14]. In this 
aspect, DCs are a fascinating target for controlling allergic diseases such as bronchial asthma.

Combination therapy with inhaled corticosteroids (ICS) and long acting $\beta 2$ adrenergic agonists (LABAs) is generally used for the treatment of asthma [15]. The addition of LABAs to moderate doses of ICS has been reported to have greater benefit than double doses of ICS in symptomatic asthmatic patients [16]. Some explanations for this observation have been proposed. Firstly, drug delivery of ICS is improved by LABAs. Secondly, LABAs enhance the function of glucocorticoid receptors in airway smooth muscle cells and epithelial cells [17]. It is also possible that LABAs attenuate inflammatory cell responses [15,18], although the precise mechanism for this requires further clarification.

The function of LABAs is mediated by the $\beta 2$ adrenergic receptor (ADR) expressed on numerous cell types, including immune cells [19]. The APC activity of Langerhans cells in the skin was suppressed by epinephrine and norepinephrine through $\beta 2$ ADR [20]. Conversely, Yanagawa and colleagues reported that $\beta 2$ ADR stimulation enhanced IL-33 production by DCs, and referred to a possible role of $\beta 2$ agonists in the stress-related progression of Th2-associated disorders [21]. Based on these findings, we aimed to investigate the impact of $\beta 2$ adrenergic agonists, especially an LABA, on the function of DCs in an HDM-induced allergic airway inflammation model. This is the first report of an LABA significantly suppressing allergic airway inflammation through DCs.

\section{Methods}

\section{Allergen and chemicals}

Two batches of house dust mite (HDM) extract from Dermatophagoides farina (Der f) were provided by ITEA Inc. (Tokyo, Japan) as a lyophilized preparation of milled mites. Formoterol (FORM) was provided by Astellas Pharma Inc. (Tokyo, Japan). ADR antagonists used were propranolol for $\beta 1+\beta 2$, ICI118,551 for $\beta 2$, CGP20712A for $\beta 1$, prazosin for $\alpha_{1}$ and yohimbine for $\alpha_{2}$-ADR respectively (Sigma-Aldrich Co. LLC., St. Louis, MO). Phenylmethylsulfonyl fluoride (PMSF), aprotinin, leupeptin, epinephrine, phorbol 12-myristate 13-acetate (PMA) and ionomycin were purchased from Sigma-Aldrich Co. LLC.

\section{Mice}

Female BALB/c mice (6-8 weeks old, Japan SLC Inc., Hamamatsu Japan) were maintained at the Saga University animal facility under specific pathogen free conditions. Animal experiments were undertaken following the guidelines for care and use of experimental animals of the Japanese Association for Laboratory Animals Science (1987) and were approved by the Saga University Animal Care and Use Committee.

\section{Protocol for HDM induced airway inflammation model}

Mice were inoculated intranasally with $25 \mu \mathrm{g}$ HDM or vehicle on days 0,7 and 14. Mice were challenged intranasally with $5 \mu \mathrm{g}$ HDM on days 21, 22 and 23. On day 24, mice were euthanized by intraperitoneal injection of sodium pentobarbital. Serum, bronchoalveolar lavage (BAL) fluid and lung tissue were harvested for further analysis (Figure 1a). FORM (12.5 ng/animal) was administered subcutaneously three times per week. FORM was dissolved in ethanol $10 \mathrm{mg} / \mathrm{ml}$ as a central stock, then was diluted optimal concentration using PBS. On the day when HDM was given, FORM was administered 30 minutes before the HDM inoculation.

\section{Collection of blood and BAL fluid}

Blood and BAL fluid samples were collected as described previously [22]. Briefly, blood was collected by right ventricle puncture. Serum was collected by centrifugation of whole blood at $8,000 \times \mathrm{g}$ for $5 \mathrm{~min}$ at $4^{\circ} \mathrm{C}$ and stored at $-80^{\circ} \mathrm{C}$ until needed. Then a 20 -gauge tube was inserted into the trachea and the lungs were lavaged twice with $1.0 \mathrm{ml}$ of saline. The cell suspension was centrifuged at $100 \times \mathrm{g}$ for $5 \mathrm{~min}$ at $4^{\circ} \mathrm{C}$. The total number of cells was counted using a hemocytometer. Cytospin samples were prepared from the cell suspension. Cell differentiation was determined by counting at least 300 leukocytes in samples stained with Diff-Quik (Siemens, Germany).

\section{Histology}

Histological examination was performed as previously reported [23]. Lungs were fixed with $10 \%$ neutralized buffered formalin (Wako, Osaka, Japan) and embedded in paraffin. Lung sections were stained with Hematoxylin and Eosin (H\&E), and periodic acid-Schiff (PAS) stains.

\section{Preparation of lung homogenate}

After bronchoalveolar lavage, the left lung was isolated and homogenized in $50 \mathrm{mM}$ Tris buffered saline ( $\mathrm{pH} 7.4)$ containing $1 \mathrm{mM}$ EDTA, $1 \mathrm{mM}$ PMSF, $1 \mu \mathrm{g} / \mathrm{ml}$ aprotinin, $1 \mu \mathrm{g} / \mathrm{ml}$ leupeptin, $1 \mathrm{mM} \mathrm{Na} \mathrm{VO}_{4}$ and $1 \mathrm{mM} \mathrm{NaF}$. The lung homogenates were centrifuged at $10,000 \times \mathrm{g}$ for $15 \mathrm{~min}$, and then supernatants were collected and stored at $-80^{\circ} \mathrm{C}$ until required.

\section{Lymphocyte stimulation in vitro}

Mice were inoculated intranasally with HDM or vehicle as described above on days 0,7 and 14. A bronchial lymph node was removed on day 17 , crushed gently and a single cell suspension prepared by passing through a $40 \mu \mathrm{m}$ nylon mesh (BD Falcon, Franklin Lakes, NJ). Lymphocytes were stimulated with $25 \mathrm{ng} / \mathrm{ml}$ PMA and $1 \mu \mathrm{g} / \mathrm{ml}$ ionomycin for 4 hours. After stimulation, supernatants were collected and stored at $-80^{\circ} \mathrm{C}$. 

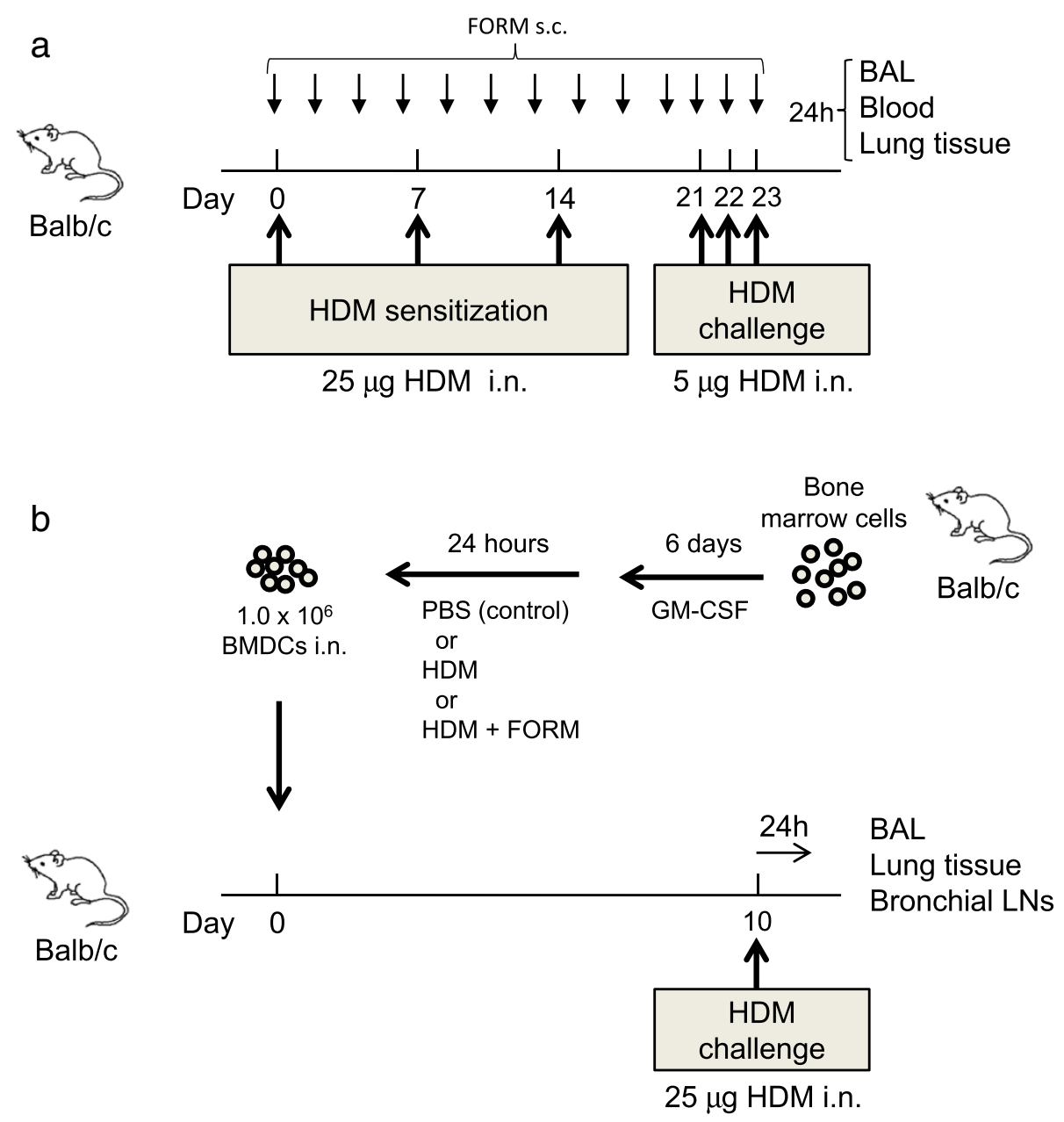

Figure 1 Protocols for the HDM-induced airway inflammation model. (a) HDM-induced airway inflammation model. Female BALB/C mice were sensitized three times intranasally with $25 \mu \mathrm{g} \mathrm{HDM}$ at days 0,7 and 14, and challenged three times intranasally with $5 \mu \mathrm{g}$ HDM at days $21-23$. Twenty-four hours after the final challenge, blood samples, BAL fluid and lung tissues were collected. BALB/c mice receiving PBS at sensitization and challenge were used as controls. (b) BM cells were harvested from BALB/C mice. DCs were generated by culturing BM cells with 10\% FBS and $10 \mathrm{ng} / \mathrm{ml}$ GM-CSF in the culture medium for 7 days. On day 7, DCs were stimulated with HDM or HDM + FORM or PBS (control) for 24 hours. One million DCs were intranasally injected into BALB/C mice on the following day. After 10 days, recipient mice were challenged intranasally with $25 \mu \mathrm{HDM}$. Twenty-four hours after the injection, blood samples, BAL fluid and lung tissues were collected. BALB/c mice receiving unstimulated DCs served as controls.

\section{Measurement of cytokines by ELISA}

IL-4, IL-6, IL-10, IL-13, IL-5, IL-17 and IL-23 were measured using a Quantikine ELISA Kit (R\&D systems Inc., Minneapolis, MN) according to the manufacturer's instructions. All samples were measured in duplicate.

Preparation of bone marrow derived dendritic cells and in vitro stimulation

Bone marrow (BM) cells were isolated from BALB/c mice as previously reported [24]. BM cells were resuspended at $2.0 \times 10^{6}$ cells $/ \mathrm{ml}$ in RPMI1640 medium supplemented with $10 \%$ fetal calf serum (FCS). The cells were cultured in the presence of $10 \mathrm{ng} / \mathrm{ml}$ recombinant murine GM$\mathrm{CSF}$ ( $\mathrm{R} \& \mathrm{D}$ systems) at $37^{\circ} \mathrm{C}$ in a humidified atmosphere containing $5 \% \mathrm{CO}_{2}$ for 6 days. On day 6, cells were harvested. More than $95 \%$ of the cells were positively stained with CD11c, and were used as myeloid dendritic cells (BMDCs) in the following experiments. BMDCs were stimulated with $10 \mu \mathrm{g} / \mathrm{ml}$ HDM, with or without FORM or epinephrine, for 24 hours. BMDCs were pretreated with $1 \mu \mathrm{M}$ of propranolol, ICI118,551, CGP20712A, prazosin or yohimbine. BMDC supernatants were collected and stored at $-80^{\circ} \mathrm{C}$.

\section{Adoptive transfer of BMDCs}

As shown in Figure 1b, BMDCs were stimulated with $10 \mu \mathrm{g} / \mathrm{ml} \mathrm{HDM}$, with or without $100 \mathrm{pM}$ FORM for 24 hours. BMDCs were collected and washed twice, and then $1.0 \times 10^{6}$ BMDCs were administered to naïve BALB/ c mice intranasally. On day 10 , mice were challenged with 
$25 \mu \mathrm{g}$ HDM. Twenty four hours later, BAL fluid and bronchial lymph nodes were collected as described above. Lymphocytes were stimulated with $25 \mathrm{ng} / \mathrm{ml}$ PMA and $1 \mu \mathrm{g} / \mathrm{ml}$ ionomycin for 4 hours. After stimulation, supernatants were collected and stored at $-80^{\circ} \mathrm{C}$.

\section{Measurement of serum Der $f$ specific IgG}

To measure Der f-specific IgG, MaxiSorp plates (Nunc, Roskilde, Denmark) were coated with $0.25 \mu \mathrm{g} / \mathrm{ml}$ Der $\mathrm{f}$ (Seikagaku co. Tokyo). Plates were washed with $0.1 \mathrm{M}$ phosphate-buffered saline (PBS) containing 0.05\% Tween 20. Each well was filled with a blocking solution of $1 \%$ BSA (Sigma-Aldrich) in PBS, and incubated for 1 hour. After washing 3 times, $100 \mu \mathrm{l} /$ well of serum was added and the plates incubated for 1 hour. After washing, IgG1 bound to the plate was detected using biotin-labeled rat anti-mouse IgG1 (Bio-Rad AbD Serotec Ltd, Oxford UK), HRP-streptavidin (Sigma-Aldrich), and 3,3,5,5'-tetramethylbenzidine (TMB, Invitrogen, CA). The amount of specific antibody was expressed as laboratory units (LU), and samples were compared with a standard serum containing Der f-specific IgG1.

\section{Statistical analysis}

The data are shown as mean \pm standard deviation (SD). Analysis of variance (ANOVA) was used for multiple comparison of continuous variables. When there was a significant difference, the difference between each group was tested using Scheffe's test. All tests were two-sided with a five percent level of significance.

\section{Results}

\section{Formoterol treatment suppressed HDM-induced airway} inflammation

We investigated the effect of the $\beta 2$ adrenergic agonist, FORM, on HDM-induced airway inflammation. Mice were sensitized and challenged with HDM, which resulted in an increase of total cells, neutrophils, lymphocytes and eosinophils in BAL fluid. FORM treatment significantly suppressed BAL cell numbers (Figure 2a). Differences between the two groups were as follows; total number of cells; $16.3 \pm 5.3$ and $5.3 \pm 2.4 \times 10^{4} / \mathrm{ml}(p<0.01)$, neutrophils; $5.4 \pm 2.9$ and $1.4 \pm 1.0 \times 10^{4} / \mathrm{ml}(p<0.01)$, lymphocytes; $0.9 \pm 0.8$ and $0.5 \pm 0.4 \times 10^{4} / \mathrm{ml} \quad(p=0.45)$, and eosinophils; $2.8 \pm 1.6$ and $0.5 \pm 0.6 \times 10^{4} / \mathrm{ml}(p<0.01)$ in HDM mice and FORM treated mice, respectively. Histological examination showed that inflammatory cell infiltration and goblet cell metaplasia were suppressed by FORM (Figure 2b). The concentrations of IL-4 and IL-17 in lung tissue were significantly decreased in FORM treated mice (Figure 2c, 2f). IL-4 concentration was $19.8 \pm 2.9$ and $9.1 \pm$ $3.3 \mathrm{pg} / \mathrm{ml}(p<0.01)$ and IL-17 was $143.6 \pm 63.1$ and $47.4 \pm$ $33.5 \mathrm{pg} / \mathrm{ml}(p<0.01)$ in HDM mice and FORM treated mice, respectively. There was no difference in the concentration of IL-13 $(118.4 \pm 61.4 \mathrm{pg} / \mathrm{ml}$ in FORM v.s. $168.9 \pm 39.8 \mathrm{pg} / \mathrm{ml}$ in HDM ), IL-5 $(17.8 \pm 7.6 \mathrm{pg} / \mathrm{ml}$ in FORM v.s. $21.9 \pm 6.5 \mathrm{pg} / \mathrm{ml}$ in HDM )in lung tissue respectively (Figure 2d, 2e). The titer of serum HDM specific IgG in FORM mice $(920.7 \pm 600.3 \mathrm{LU} / \mathrm{ml})$ was similar to that in the serum of HDM mice $(1,270.0 \pm 920.5 \mathrm{LU} / \mathrm{ml})$ (Figure 2g).

\section{FORM treatment decreased Th2 and Th17 lymphocytes in bronchial lymph nodes}

We next examined whether FORM attenuates the T cell response to HDM in regional lymph nodes. HDM treatment caused an increase in the concentration of IL-4, IL-13 and IL17 in supernatant of lymphocytes (Figure 3). Lymphocytes from FORM treated mice produced significantly less cytokines; IL-4; $104.7 \pm 2.8$ and $91.5 \pm 3.9 \mathrm{pg} / \mathrm{ml}$ $(p<0.01), \quad$ IL-13; $205.7 \pm 14.3$ and $103.6 \pm 4.3 \mathrm{pg} / \mathrm{ml}$ $(p<0.01), \mathrm{IL}-5 ; 37.4 \pm 2.5$ and $21.1 \pm 3.0 \mathrm{pg} / \mathrm{ml}(p<0.01)$, and IL-17, $94.7 \pm 15.4$ and $58.5 \pm 2.2 \mathrm{pg} / \mathrm{ml}(p<0.01)$, in HDM and HDM/FORM treated mice, respectively. These finding suggest that FORM attenuates the Th2 and Th17 responses to HDM in vivo.

To eliminate the possibility that FORM directly affects cytokine production from lymphocytes, lymph node cells harvested from HDM mice were stimulated with PMA and ionomycin in the presence of various concentrations of FORM in vitro. As shown in Table 1, FORM concentrations of up to $10,000 \mathrm{pM}$ did not alter IL-4, IL-13 or IL-17 production from lymphocytes.

\section{FORM modulated cytokine production from DCs}

We hypothesized that the suppression of $\mathrm{T}$ cell responses by FORM in vivo was mediated by DCs. We therefore examined the effect of FORM on cytokine production by BMDCs in vitro. BMDCs produced IL23 and IL- 6 after HDM stimulation. IL-23 production was suppressed by both FORM and epinephrine in a dose dependent manner (Figure 4a), where the effect of FORM was 10,000 times stronger than epinephrine. IL-6 production was also suppressed by FORM, but not by epinephrine at concentrations of up to $10^{-7} \mathrm{M}$ (Figure 4b). IL-10 production from DCs was enhanced by FORM and epinephrine in a dose dependent manner (Figure 4c).

The effect of FORM on BMDCs was mediated by $\beta 2$ ADR

We examined whether the effect of FORM is mediated specifically by ADR. To clarify which ADR contribute to the suppression of cytokine production by FORM, specific ADR antagonists used were propranolol for $\beta 1+\beta 2$, ICI118,551 for $\beta 2$, CGP20712A for $\beta 1$, prazosin for $\alpha 1$ and yohimbine for $\alpha 2$-ADR respectively. IL-23 production from HDM-stimulated BMDCs was suppressed by FORM, $195.2 \pm 38.6 \mathrm{pg} / \mathrm{ml}$, but was significantly restored 

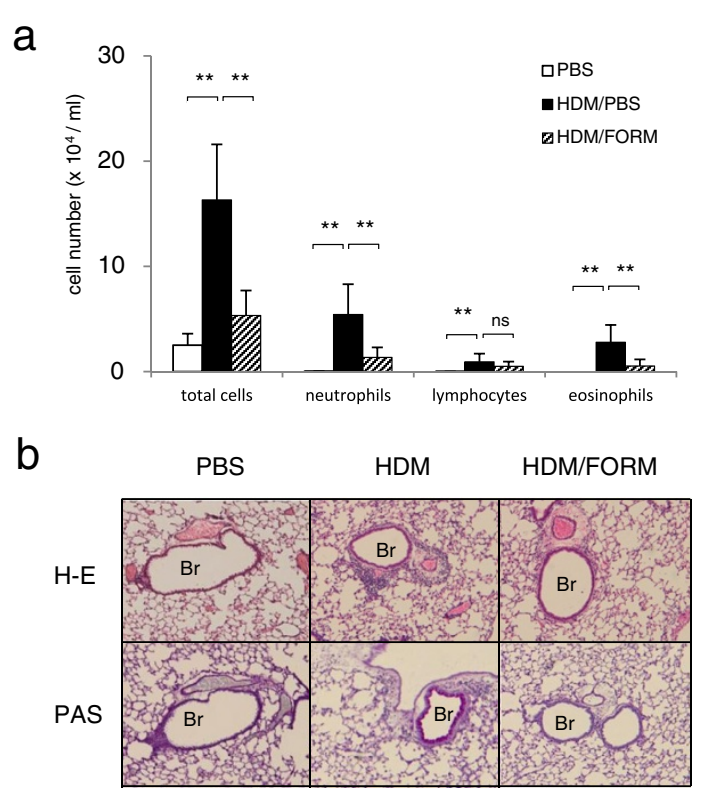

C
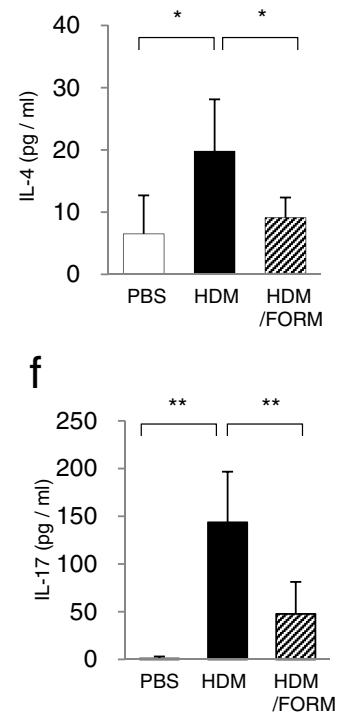

d

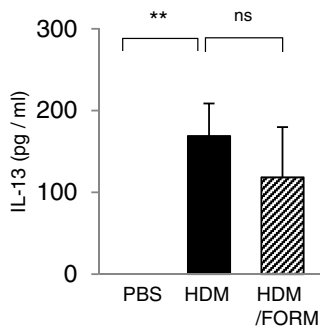

e
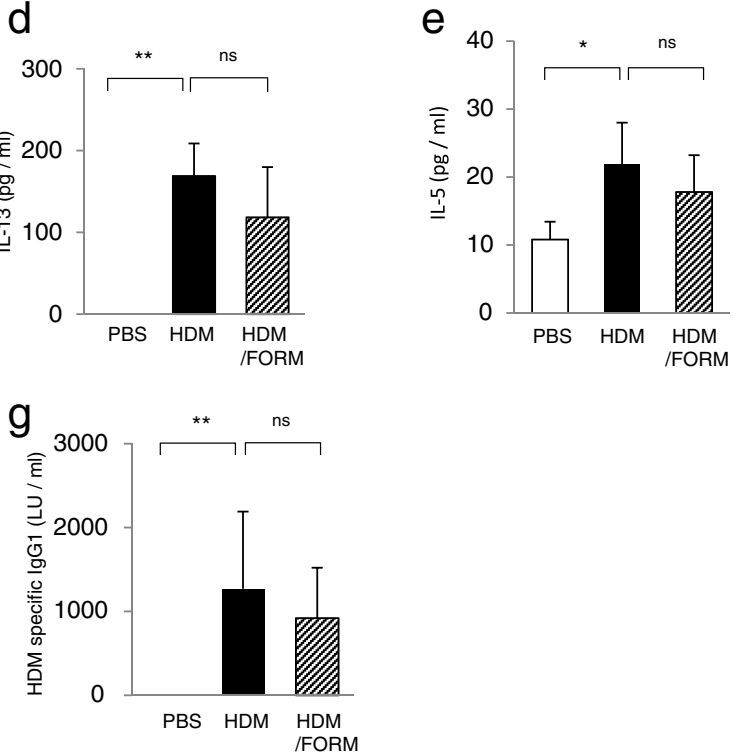

Figure 2 Formoterol-suppressed HDM-induced airway inflammation. (a) Total and differential cell counts in BAL fluids. ( $n=6$ in each group) (b) Histological examination of airway inflammation. Sections were stained with H\&E (upper panels) or PAS (lower panels). Original magnification was $\times 200$. Br indicates bronchus. Concentrations of $(\mathbf{c}) \mathrm{IL}-4$, (d) $\mathrm{IL}-13$, (e) IL-5 and (f) IL-17 in the lung tissues were measured by ELISA. ( $\mathrm{n}=6 \mathrm{in}$ each group) (g) Titers of HDM specific lgG1 in the serum are shown. ${ }^{*} p<0.01,{ }^{* *} p<0.05$.

to $301.9 \pm 1.8 \mathrm{pg} / \mathrm{ml}$ (Figure $5 \mathrm{a}$ ) when propranolol was added. ICI118,551 also significantly restored IL-23 production to $355.5 \pm 29.5 \mathrm{pg} / \mathrm{ml}$, while CGP20712A did not. Propranolol and ICI118,551 restored IL-6 production suppressed by FORM, but CGP20712A did not (Figure $5 \mathrm{~b}$ ). Interestingly, IL-10 production from HDMstimulated DCs enhanced by FORM, $151.3 \pm 17.0 \mathrm{pg} / \mathrm{ml}$, was significantly decreased in a $\beta_{2}$ ADR pathway dependent manner (Figure 5c).
We used epinephrine, a full agonist for all classes of $\mathrm{ADR}$, to investigate whether the modulation of DC cytokine production is mediated specifically by $\beta 2$ ADR. The suppression of IL-23 production by epinephrine, 137.4 \pm $21.4 \mathrm{pg} / \mathrm{ml}$, was restored, to $182.3 \pm 10.7 \mathrm{pg} / \mathrm{ml}$ by propranolol, and to $248.0 \pm 26.1 \mathrm{pg} / \mathrm{ml}$ by ICI118,551. IL-23 production could not be restored by CGP20712A (105.4 \pm $11.6 \mathrm{pg} / \mathrm{ml})$, prazosin $(121.6 \pm 5.5 \mathrm{pg} / \mathrm{ml})$ or yohimbine $(124.5 \pm 4.5 \mathrm{pg} / \mathrm{ml})$ (Figure $5 \mathrm{~d}$ ). The suppression of IL-6 


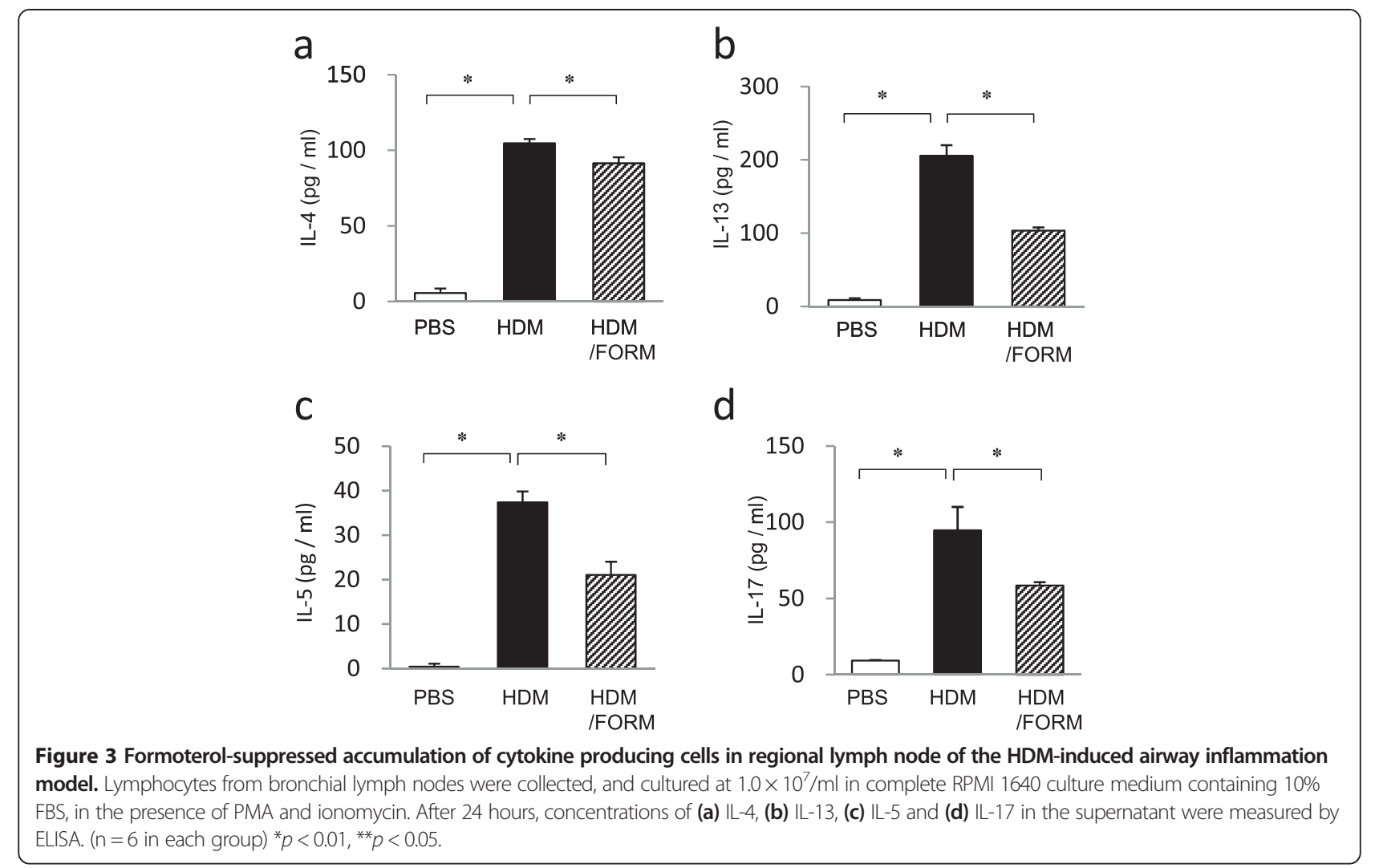

production by $1 \mu \mathrm{M}$ epinephrine, $12.3 \pm 2.4 \mathrm{ng} / \mathrm{ml}$, was also restored to $20.9 \pm 2.3 \mathrm{ng} / \mathrm{ml}$ by propranolol, and to $22.6 \pm$ $2.5 \mathrm{ng} / \mathrm{ml}$ by ICI118,551. IL-6 production could not be restored by CGP20712A $(14.2 \pm 1.2 \mathrm{ng} / \mathrm{ml})$, prazosin $(13.6 \pm$ $0.7 \mathrm{ng} / \mathrm{ml}$ ) or yohimbine $(13.1 \pm 0.6 \mathrm{ng} / \mathrm{ml}$ ) (Figure $5 \mathrm{e})$. On the contrary, enhanced IL-10 production by epinephrine, $172.0 \pm 11.1 \mathrm{pg} / \mathrm{ml}$, was significantly reduced to $92.8 \pm$ $2.7 \mathrm{pg} / \mathrm{ml}$ by propranolol and to $86.1 \pm 5.9 \mathrm{pg} / \mathrm{ml}$ by ICI118,551 (Figure 5f).

\section{HDM-induced airway inflammation was attributed to cytokines produced by DCs}

To examine whether the effect of FORM on HDMinduced airway inflammation in vivo depends on DCs, we performed adoptive transfer of HDM-pulsed BMDCs to naïve mice. When intranasal administration of HDMpulsed DCs was followed by HDM challenge, the total number of cells $\left(31.2 \pm 13.5 \times 10^{4} / \mathrm{ml}\right)$, eosinophils $(2.3 \pm$ $\left.1.4 \times 10^{4} / \mathrm{ml}\right)$ and neutrophils $\left(13.1 \pm 6.9 \times 10^{4} / \mathrm{ml}\right)$ in BAL fluids was significantly increased compared with mice given sham-pulsed DC and HDM challenge (Figure 6a). BAL cell counts in the latter group were total cells; $12.1 \pm$ $6.3 \times 10^{4} / \mathrm{ml}$, eosinophils; $0.4 \pm 0.4 \times 10^{4} / \mathrm{ml}$, and neutrophils; $3.6 \pm 3.4 \times 10^{4} / \mathrm{ml}$. When DCs pulsed with HDM in the presence of 100 pM FORM in vitro were administered to mice, the BAL cell numbers were significantly decreased in comparison to HDM group; total cells; $19.0 \pm$ $3.3 \times 10^{4} / \mathrm{ml} \quad(p<0.05), \quad$ eosinophils; $0.3 \pm 0.3 \times 10^{4} / \mathrm{ml}$ $(p<0.05)$, and neutrophils; $5.0 \pm 0.9 \times 10^{4} / \mathrm{ml} \quad(p<0.05)$, respectively (Figure 6a).

Mice given HDM-pulsed DCs and antigen challenge showed lymphocyte responses similar to mice directly sensitized with HDM. The concentration of IL-4, IL-13, IL-5 and IL-17 in lymph node cell culture was $82.1 \pm$ $31.8 \mathrm{pg} / \mathrm{ml}, 108.9 \pm 32.8 \mathrm{pg} / \mathrm{ml}, 19.3 \pm 6.9 \mathrm{pg} / \mathrm{ml}$, and $181.7 \pm 79.6 \mathrm{pg} / \mathrm{ml}$, in the HDM-pulsed DC group, and

Table 1 FORM did not have a direct effect on cytokine production from lymphocytes

\begin{tabular}{|c|c|c|c|c|c|}
\hline Mice treated with & Saline & $\mathrm{HDM} 10 \mathrm{mg} / \mathrm{ml}$ & $\mathrm{HDM} 10 \mathrm{mg} / \mathrm{ml}$ & HDM $10 \mathrm{mg} / \mathrm{ml}$ & $\mathrm{HDM} 10 \mathrm{mg} / \mathrm{ml}$ \\
\hline FORM added in vitro & $0 \mathrm{pM}$ & $0 \mathrm{pM}$ & 10pM & 100pM & $1 \mathrm{nM}$ \\
\hline IL-4 (pg/ml) & $3.7 \pm 0.5$ & $28.7 \pm 2.8$ & $27.2 \pm 3.0^{\#}$ & $28.5 \pm 2.0^{\#}$ & $28.0 \pm 2.6^{\#}$ \\
\hline IL-13 (pg/ml) & $7.0 \pm 15.3$ & $75.1 \pm 6.0$ & $72.3 \pm 12.5^{\#}$ & $67.9 \pm 14.4^{\#}$ & $70.8 \pm 12.6^{\#}$ \\
\hline IL-17 (pg/ml) & $13.2 \pm 3.0$ & $41.6 \pm 0.3$ & $39.9 \pm 2.3^{\#}$ & $41.6 \pm 3.0^{\#}$ & $40.6 \pm 2.1^{\#}$ \\
\hline
\end{tabular}

\#There were no significant difference compared with HDM. 

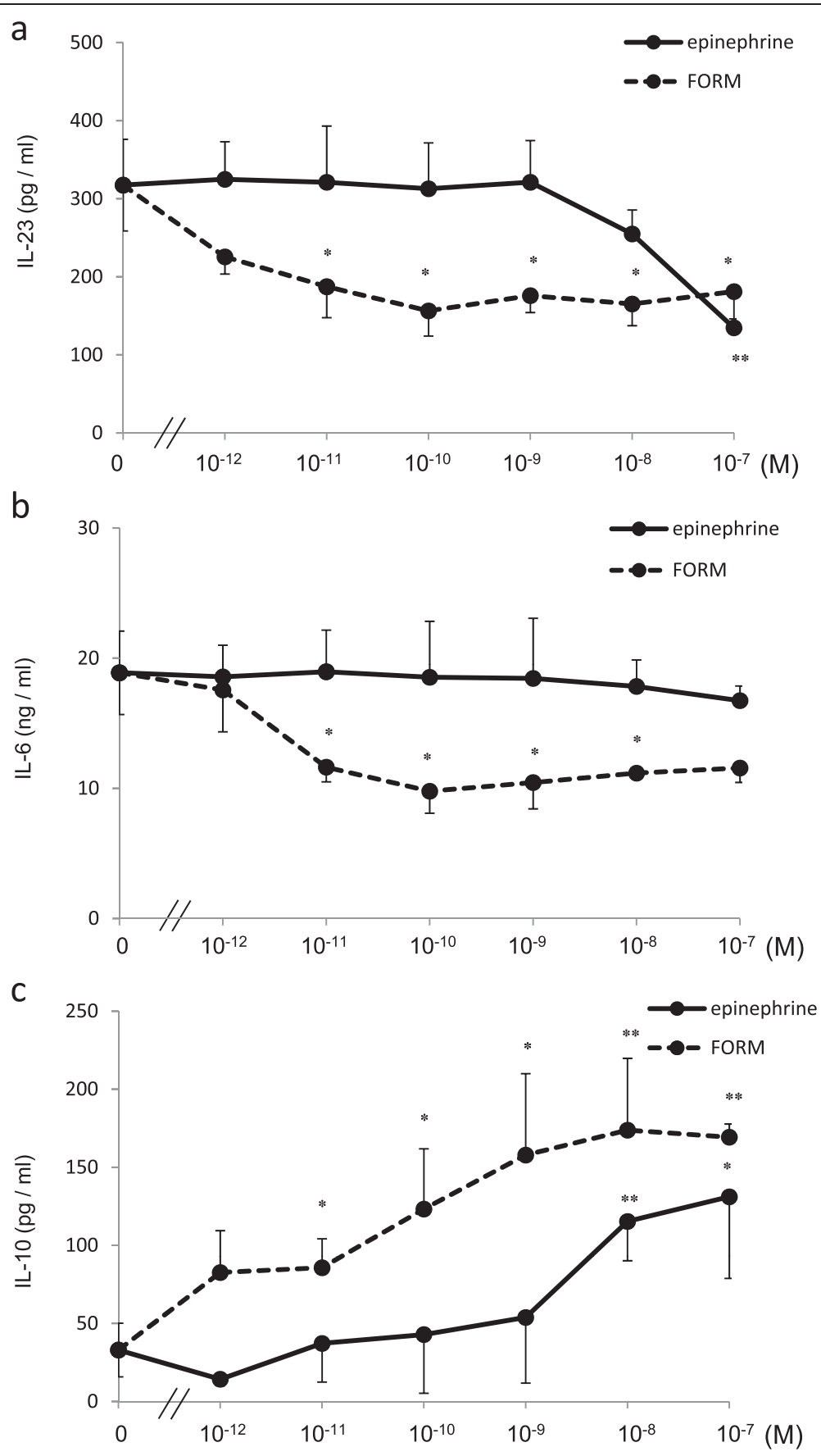

Figure 4 Formoterol- and epinephrine-attenuated cytokine production from DCs in a $\beta_{2}$ adrenergic receptor and dose dependent manner. BMDCs, $1.0 \times 10^{6} / \mathrm{ml}$ in complete media, were stimulated by $10 \mu \mathrm{g} \mathrm{HDM}$ in the presence of various concentrations of FORM or epinephrine for 24 hours. Supernatants were collected, and concentrations of (a) IL-23, (b) IL-6 and (c) IL-10 were measured by ELISA. ${ }^{*} p<0.01$, ${ }^{* *} p<0.05$.

$35.9 \pm 30.3 \mathrm{pg} / \mathrm{ml}, 63.0 \pm 26.2 \mathrm{pg} / \mathrm{ml}, 13.7 \pm 6.2 \mathrm{pg} / \mathrm{ml}$, and $43.1 \pm 24.6 \mathrm{pg} / \mathrm{ml}$, in the sham-pulsed DC group, respectively (Figure 6b-e). Significant differences between the two groups were found for levels of IL-4 $(p<0.05)$, IL-13 $(p<0.05)$ and IL-17 $(p<0.05)$. When DCs were pulsed with HDM in the presence of FORM, the concentration of IL-4, IL-13, IL-5 and IL-17 in lymph node cell culture supernatants decreased to $45.6 \pm$ $21.6 \mathrm{pg} / \mathrm{ml}, 61.4 \pm 24.9 \mathrm{pg} / \mathrm{ml}, 17.3 \pm 5.1 \mathrm{pg} / \mathrm{ml}$, and $76.3 \pm$ $56.2 \mathrm{pg} / \mathrm{ml}$, respectively. The difference between the HDM group and the HDM/FORM group was significant for levels of IL-13 and IL-17 $(p<0.05)$. 

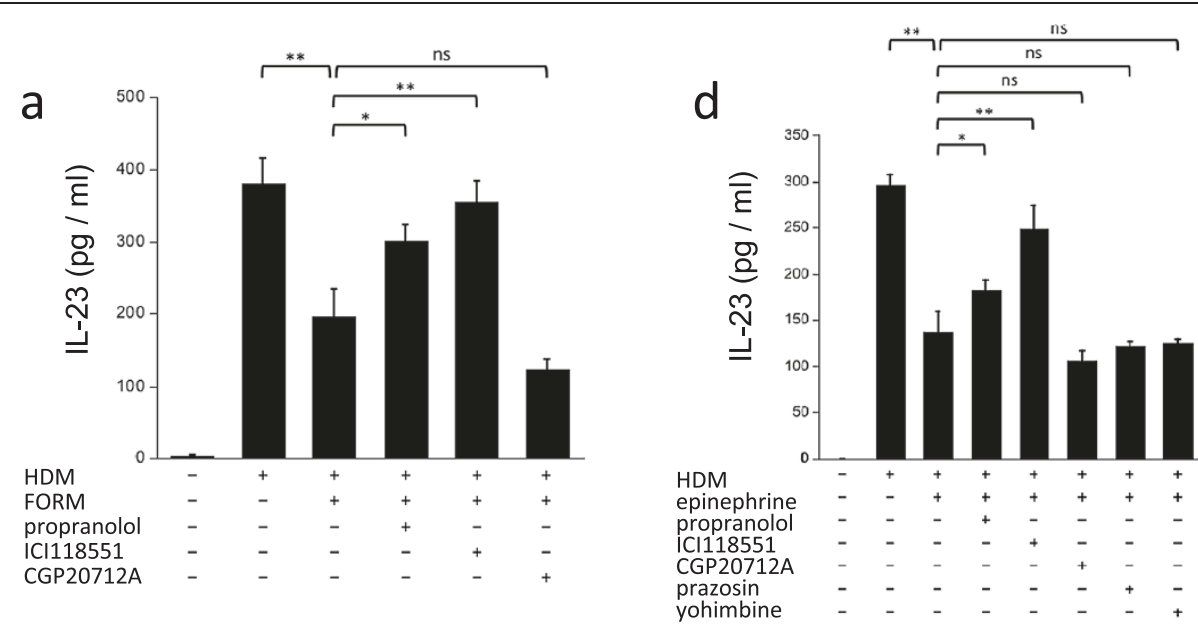

b
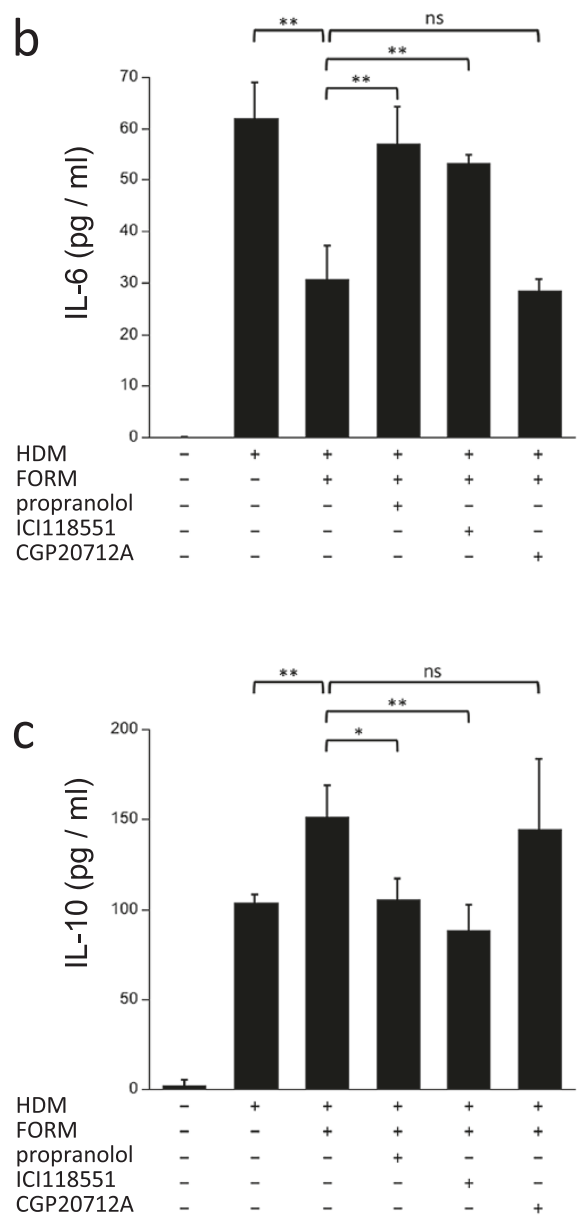

e
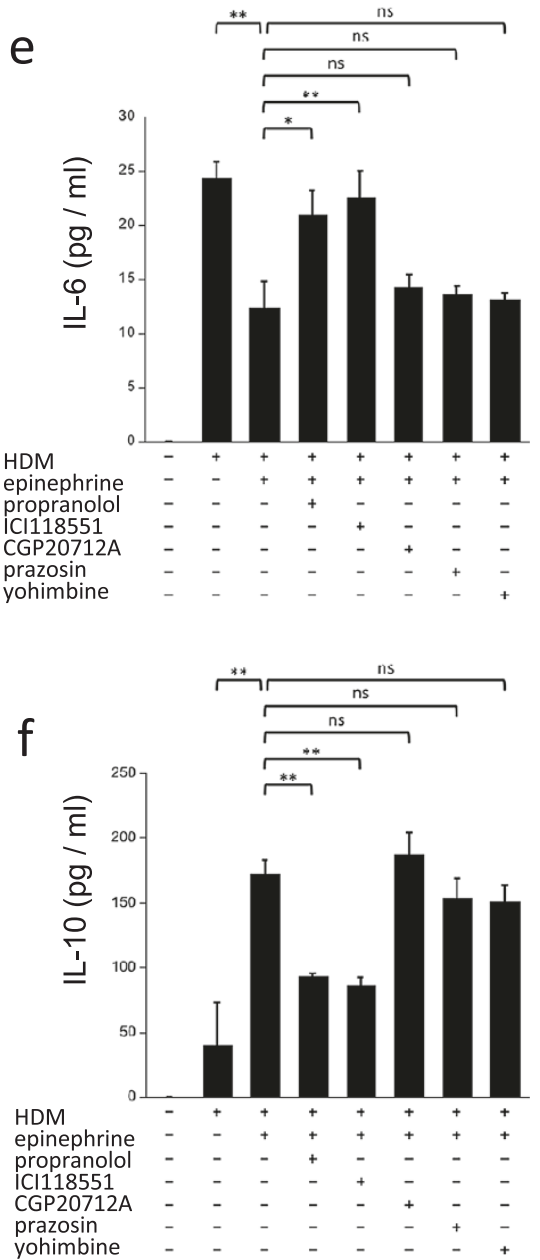

Figure 5 The effect of FORM and epinephrine on DCs was mediated specifically by the $\boldsymbol{\beta}_{2}$ adrenergic receptor. BMDCs were cultured with $10 \mu \mathrm{g} \mathrm{HDM}$ and $100 \mathrm{pM}$ FORM. The effect of various ADR antagonists on cytokine production was examined, (a) IL-23, (b) IL-6 and (c) IL-10. BMDCs were cultured with $10 \mu \mathrm{g} \mathrm{HDM}$ and $1 \mu \mathrm{M}$ epinephrine. The effect of various ADR antagonists on cytokine production was examined, (d) IL-23, (e) IL-6 and (f) IL-10. ${ }^{*} p<0.01,{ }^{* *} p<0.05$. 

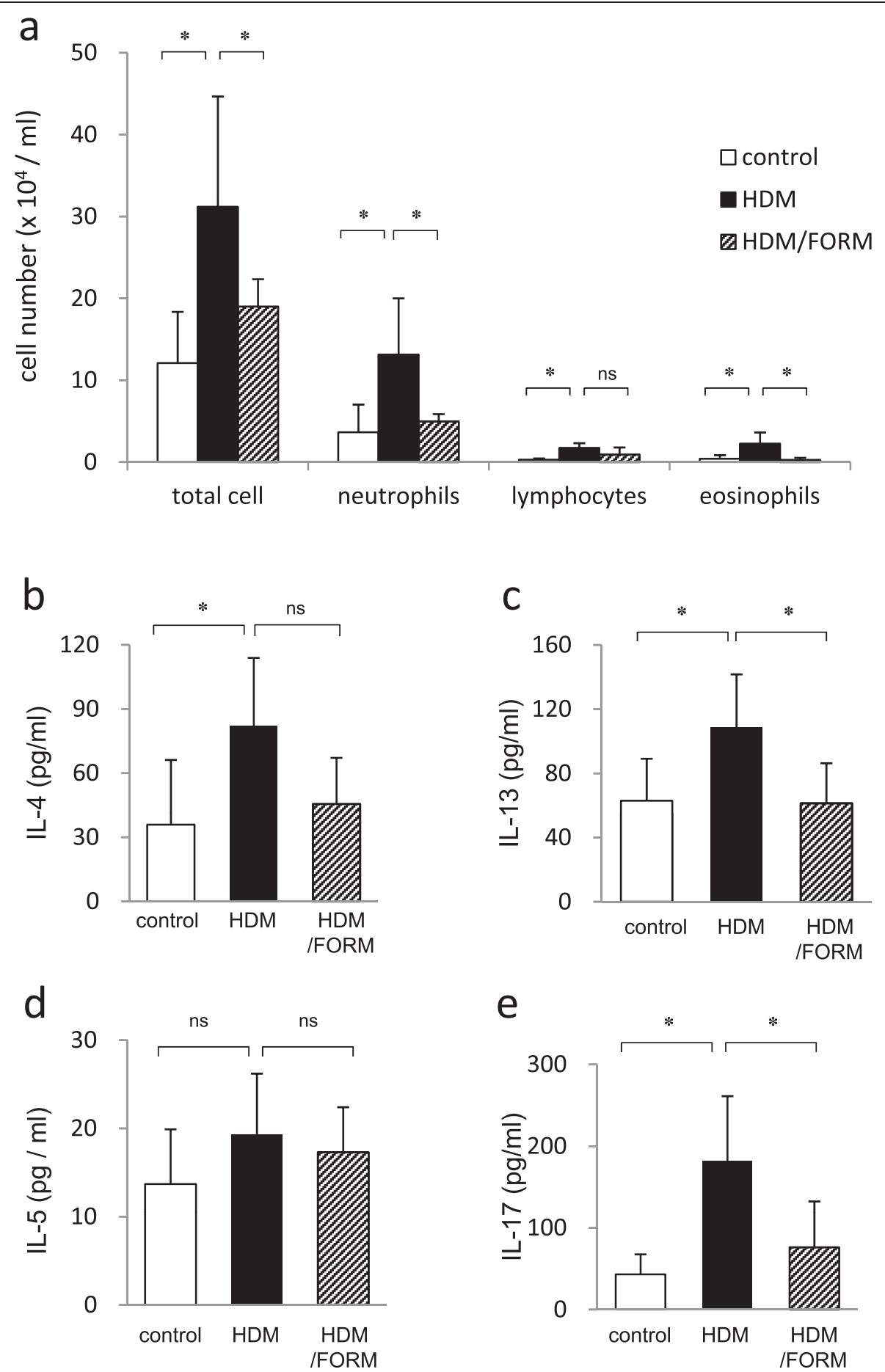

Figure 6 The effect of Formoterol on the DC adoptive transfer model. BMDCs were stimulated with $10 \mu \mathrm{g} / \mathrm{ml}$ HDM in the presence or absence of 100 pM FORM for 24 hours. BMDCs were collected and washed twice with PBS, then $1.0 \times 10^{6}$ BMDCs in $50 \mu$ PBS were administered to naïve BALC/C mice intranasally. Control mice were administrated $1.0 \times 10^{6}$ BMDCs without HDM and FORM stimulation ( $n=6$ in each group). On day 10, mice were challenged with $25 \mathrm{\mu g} \mathrm{HDM}$. Twenty four hours later, mice were euthanized and BAL fluid and bronchial lymph nodes (LNs) were collected. (a) Total and differential cell counts in BAL fluids. After harvesting, bronchial lymph node cells were cultured in the presence of PMA and ionomycin. Concentrations of (b) IL-4, (c) IL-13, (d) IL-5 and (e) IL-17 in the supernatant were measured by ELISA. ${ }^{*} p<0.01,{ }^{* *} p<0.05$. 


\section{Discussion}

In this study we demonstrated that FORM suppressed both HDM-induced accumulation of inflammatory cells in the airway and goblet cell metaplasia of airway epithelium in mice. These effects were associated with decreased IL-4 and IL-17 in lung homogenate and decreased accumulation of Th2- and Th17-cytokine production in regional lymph nodes. These observations raise the possibility that $\beta 2$ adrenergic agonists can attenuate response of DCs to HDM and thus lead to modulation of $\mathrm{T}$ cell function.

DCs contribute to the initial step of an allergic response after environmental exposure, and play a key role as APC in helper T cell responses [11]. DCs induce naïve lymphocytes to differentiate into Th2 or Th17 cells through production of IL-6 and IL-23 [25,26]. Recent evidence has shown that catecholamines can regulate the immune response through DCs. Antigen presentation by Langerhans cells in the skin was suppressed by epinephrine and norepinephrine in a $\beta 2$ ADR dependent manner [20]. Crosstalk between TLR4 and $\beta 2$ ADR transduction pathways in DCs was demonstrated in vitro and in vivo [27]. Matsushita and colleagues reported that dopamine D1-like antagonists attenuate the Th17mediated immune response through DCs and airway inflammation [28]. Therefore, we hypothesized that a $\beta 2$ ADR agonist has inhibitory effects in allergic airway inflammation.

We demonstrated that FORM suppressed IL- 6 and IL23 production from BMDCs in vitro and that production was restored by treatment of DCs with $\beta 2$ ADR antagonists. Furthermore, epinephrine, a full agonist for $\alpha$ and $\beta$ ADRs, also suppressed cytokine production, which was restored by $\beta 2$ selective ADR antagonists but not by other classes of ADR antagonists. These observations suggest that the effect of FORM and epinephrine on $\mathrm{BMDC}$ is specific and mediated by the $\beta 2 \mathrm{ADR}$ signaling pathway. The effect of FORM was about 10,000 times stronger than that of epinephrine which may be explained by the nature of FORM as a long acting $\beta 2$ agonist. FORM initially diffuses into the plasma membrane of cells, and then is slowly released from the cell, where it can come into contact with $\beta 2$ ADR [29]. Interestingly, IL-10 production from DCs was enhanced by both FORM and epinephrine. IL-10 is known as an inhibitory cytokine in allergic airway inflammation [30]. Enhanced IL-10 production in DCs contributes to selflimiting airway inflammation. Taken together, these data indicate that a $\beta 2$ ADR agonist can modulate the function of HDM-stimulated BMDC and suppress allergic inflammation.

A recent study reported that repeated challenge with methacholine caused bronchoconstriction without additional airway inflammation and airway remodeling in asthmatic patients [31]. This finding raises a question that FORM suppressed bronchoconstriction and thus inhibits lymphocyte reactions. To address this question, we conducted a BMDC adoptive transfer experiment. The treatment of BMDCs by FORM suppressed airway inflammation and accumulation of Th2/Th17 cytokine producing lymphocytes in regional lymph nodes. These results strongly suggest that $\beta 2$ ADR stimulation can attenuate inflammatory processes in an HDM-induced airway inflammation model, through modulation of DC function.

The effect of ICS on airway inflammation and hyperresponsiveness is well established. Nevertheless, there remain some issues to be solved. Firstly, a number of patients have airway inflammation resistant to ICS. Bronchial asthma is a heterogeneous disease with several proposed clinical phenotypes [32]. Among them, IL-4 and IL-13-mediated severe atopic asthma with elevated serum IgE and periostin can be treated effectively with an anti-IgE monoclonal antibody, omalizumab, or an anti-IL-13 monoclonal antibody, lebrikizumab [33-36]. Severe non-atopic eosinophilic asthma of late onset is often associated with chronic sinusitis and nasal polyps. This disease is resistant to high dose ICS but responsive to systemic corticosteroids and anti-IL-5 therapy $[32,37]$. Evidence suggests the involvement of the IL-5/IL-33 signaling pathway in the pathogenesis of this phenotype $[38,39]$. Other asthmatic patients have corticosteroid resistant neutrophil-dominant disease. IL-17 has been shown to be involved in the pathogenesis of neutrophildominant asthma $[9,40,41]$. Although macrolide antibiotics may be effective in this steroid-resistant condition $[42,43]$, a better solution is required. Our finding that a long acting $\beta 2$ receptor agonist, FORM, modulates the Th17 response suggests another possible solution.

A second issue is that ICS treatment has to be continued in order to maintain a well-controlled state. In most asthmatic patients, ICS strongly suppresses airway inflammation and establishes a symptom free condition. However, ICS cannot modulate the mechanisms underlying the pathogenesis of asthma, such as atopic sensitization. Thus, once ICS is discontinued, airway inflammation gradually recurs. Asthmatic patients frequently ask their physicians how long they should continue ICS treatment once they have become free of symptoms. To best answer this question, treatment that can improve the underlying condition should be established. Immune-modulation therapies, including antigen desensitization, have been applied to asthmatic patients with modest success [44]. In animal models of airway inflammation, autoimmune encephalomyelitis, nephrotoxic serum nephritis, and rheumatoid arthritis, an antagonist to the dopamine receptor has been reported to attenuate DC function and thus the immunological response [28,45-47]. Our findings extend this concept and 
indicate for the first time that an LABA can directly suppress the immunological response in vivo.

ICS/LABA combination therapy is a widely used and reliable treatment for asthmatic patients [48,49]. However, recent studies have raised concerns about the safety of LABAs in asthma treatment, due to evidence of an increased risk of severe exacerbation of asthma symptoms leading to hospitalization in pediatric and adult patients, as well as some fatalities [50,51]. Accordingly, the U.S. Food and Drug Administration announced in February 2010 that LABAs should not be used alone in patients with asthma, and that they should be used for the shortest duration of time required achieving control of asthma symptoms [52].

\section{Conclusion}

Our findings suggested that FORM modulates dendritic cell function and attenuates Th2 and Th17 responses induced by HDM. Thus, we propose that the clinical significance of LABAs should be re-investigated taking into account these immune-modulating effects.

\section{Abbreviations}

HDM: House dust mite; Der f: Dermatophagoides farinae; LABA: Long acting beta 2 adrenergic agonist; ADR: Adrenergic receptor; ICS: Inhaled corticosteroid; FORM: Formoterol; BMDC: Bone marrow derived dendritic cell; APC: Antigen presenting cells; BAL: Bronchoalveolar lavage; H\&E: Hematoxylin and Eosin; PAS: Periodic acid-Schiff.

\section{Competing interests}

The authors declare that they have no competing interests.

\section{Authors' contributions}

GK, HT and KT carried out the experimental work, the data analysis and drafted the manuscript. KK and HS extracted the HDM antigen and participated in discussion of the experiments and results. SH and SK provided overall leadership to the experimental design, data analysis, and preparation of the manuscript. All authors read and approved the final manuscript.
}

\section{Acknowledgements}

We thank Dr. Edmund J. Miller (Feinstein Institute for Medical Research, NY, USA) for critical review of this manuscript. We also thank Dr. Shoichiro Ohta (Saga University, Saga, Japan) for technical assistance with this study.

\section{Declaration of funding sources}

This study was supported by the Young Researcher Supporting Program of Saga University (KT).

\section{Author details}

'Division of Hematology, Respiratory Medicine and Oncology, Department of Internal Medicine, Faculty of Medicine, Saga University, 5-1-1 Nabeshima, Saga 849-8501, Japan. ${ }^{2}$ Institute of Tokyo Environmental Allergy, 1-2-5, Yushima, Bunkyo-ku, Tokyo 113-0034, Japan.

Received: 29 April 2014 Accepted: 15 September 2014 Published online: 30 October 2014

\section{References}

1. Thomas WR, Hales BJ, Smith WA: House dust mite allergens in asthma and allergy. Trends Mol Med 2010, 16:321-328.

2. Morgan WJ, Crain EF, Gruchalla RS, O'Connor GT, Kattan M, Evans R 3rd, Stout J, Malindzak G, Smartt E, Plaut M, Walter M, Vaughn B, Mitchell H: Results of a home-based environmental intervention among urban children with asthma. N Engl J Med 2004, 351:1068-1080.
3. Gaffin JM, Phipatanakul W: The role of indoor allergens in the development of asthma. Curr Opin Allergy Clin Immunol 2009, 9:128-135.

4. Galli SJ, Tsai M, Piliponsky AM: The development of allergic inflammation. Nature 2008, 454:445-454.

5. Tattersfield AE, Knox AJ, Britton JR, Hall IP: Asthma. Lancet 2002, 360:1313-1322.

6. Al-Muhsen S, Johnson JR, Hamid Q: Remodeling in asthma. J Allergy Clin Immunol 2011, 128:451-462.

7. Minnicozzi M, Sawyer RT, Fenton MJ: Innate immunity in allergic disease. Immunol Rev 2011, 242:106-127.

8. Busse WW, Lemanske RF: Asthma. N Engl J Med 2001, 344:350-362.

9. Al-Ramli W, Prefontaine D, Chouiali F, Martin JG, Olivenstein R, Lemiere C, Hamid Q: T(H)17-associated cytokines (IL-17A and IL-17 F) in severe asthma. J Allergy Clin Immunol 2009, 123:1185-1187.

10. Linden A: Role of interleukin-17 and the neutrophil in asthma. Int Arch Allergy Immunol 2001, 126:179-184.

11. Banchereau J, Steinman RM: Dendritic cells and the control of immunity. Nature 1998, 392:245-252.

12. Dong C: TH17 cells in development: an updated view of their molecular identity and genetic programming. Nat Rev Immunol 2008, 8:337-348.

13. Murphy KM, Ouyang W, Farrar JD, Yang J, Ranganath S, Asnagli H, Afkarian M, Murphy TL: Signaling and transcription in T helper development. Annu Rev Immunol 2000, 18:451-494.

14. Lambrecht BN, Hammad H: The role of dendritic and epithelial cells as master regulators of allergic airway inflammation. Lancet 2010, 376:835-843.

15. Miyamoto M, Tomaki M, Lotvall J, Linden A: Beta-adrenoceptor stimulation and neutrophil accumulation in mouse airways. Eur Respir J 2004, 24:231-237.

16. Masoli M, Weatherall M, Holt S, Beasley R: Moderate dose inhaled corticosteroids plus salmeterol versus higher doses of inhaled corticosteroids in symptomatic asthma. Thorax 2005, 60:730-734.

17. Barnes PJ: Scientific rationale for using a single inhaler for asthma control. Eur Respir J 2007, 29:587-595.

18. O'Connor BJ, Fuller RW, Barnes PJ: Nonbronchodilator effects of inhaled beta 2 agonists. Greater protection against adenosine monophosphatethan methacholine-induced bronchoconstriction in asthma. Am J Respir Crit Care Med 1994, 150:381-387.

19. Nance DM, Sanders VM: Autonomic innervation and regulation of the immune system (1987-2007). Brain Behav Immun 2007, 21:736-745.

20. Seiffert K, Hosoi J, Torii H, Ozawa H, Ding W, Campton K, Wagner JA, Granstein RD: Catecholamines inhibit the antigen-presenting capability of epidermal Langerhans cells. J Immunol 2002, 168:6128-6135.

21. Yanagawa Y, Matsumoto M, Togashi H: Adrenoceptor-mediated enhancement of interleukin-33 production by dendritic cells. Brain Behav Immun 2011, 25:1427-1433.

22. Takahashi K, Koga K, Linge HM, Zhang Y, Lin X, Metz CN, Al-Abed Y, Ojamaa K, Miller EJ: Macrophage CD74 contributes to MIF-induced pulmonary inflammation. Respir Res 2009, 10:33.

23. Fukuno Y, Hayashi S, Kohsa K, Fujisawa N, Tominaga M, Miller EJ, Nagasawa K: Chemokine receptor inhibitor, Antileukinate, suppressed ovalbumininduced eosinophilic inflammation in the airway. Cytokine 2003, 22:116-125.

24. Takahashi K, Shibata T, Akashi-Takamura S, Kiyokawa T, Wakabayashi Y, Tanimura N, Kobayashi T, Matsumoto F, Fukui R, Kouro T, Nagai Y, Takatsu K, Saitoh S, Miyake K: A protein associated with Toll-like receptor (TLR) 4 (PRAT4A) is required for TLR-dependent immune responses. J Exp Med 2007, 204:2963-2976.

25. Cosmi L, Liotta F, Maggi E, Romagnani S, Annunziato F: Th17 cells: new players in asthma pathogenesis. Allergy 2011, 66:989-998.

26. Holgate ST: Innate and adaptive immune responses in asthma. Nat Med 2012, 18:673-683.

27. Herve J, Dubreil L, Tardif V, Terme M, Pogu S, Anegon I, Rozec B, Gauthier C, Bach JM, Blancou P: beta2-Adrenoreceptor agonist inhibits antigen cross-presentation by dendritic cells. J Immunol 2013, 190:3163-3171.

28. Nakagome K, Imamura M, Okada H, Kawahata K, Inoue T, Hashimoto K, Harada H, Higashi T, Takagi R, Nakano K, Hagiwara K, Kanazawa M, Dohi M, Nagata M, Matsushita S: Dopamine D1-like receptor antagonist attenuates Th17-mediated immune response and ovalbumin antigen-induced neutrophilic airway inflammation. J Immunol 2011, 186:5975-5982.

29. Teschemacher $\mathrm{A}$, Lemoine $\mathrm{H}$ : Kinetic analysis of drug-receptor interactions of long-acting beta2 sympathomimetics in isolated receptor membranes: 
evidence against prolonged effects of salmeterol and formoterol on receptor-coupled adenylyl cyclase. J Pharmacol Exp Ther 1999, 288:1084-1092.

30. Akdis CA, Akdis M: Mechanisms and treatment of allergic disease in the big picture of regulatory T cells. J Allergy Clin Immunol 2009, 123:735-746.

31. Grainge CL, Lau LC, Ward JA, Dulay V, Lahiff G, Wilson S, Holgate S, Davies $\mathrm{DE}$, Howarth PH: Effect of bronchoconstriction on airway remodeling in asthma. N Engl J Med 2011, 364:2006-2015.

32. Moore WC, Meyers DA, Wenzel SE, Teague WG, Li H, Li X, D'Agostino R Jr, Castro M, Curran-Everett D, Fitzpatrick AM, Gaston B, Jarjour NN, Sorkness R, Calhoun WJ, Chung KF, Comhair SA, Dweik RA, Israel E, Peters SP, Busse WW, Erzurum SC, Bleecker ER: Identification of asthma phenotypes using cluster analysis in the Severe Asthma Research Program. Am J Respir Crit Care Med 2010, 181:315-323.

33. Li X, Howard TD, Zheng SL, Haselkorn T, Peters SP, Meyers DA, Bleecker ER: Genome-wide association study of asthma identifies RAD50-IL13 and HLA-DR/DQ regions. J Allergy Clin Immunol 2010, 125:328-335.

34. Brasier AR, Victor S, Boetticher G, Ju H, Lee C, Bleecker ER, Castro M, Busse WW, Calhoun WJ: Molecular phenotyping of severe asthma using pattern recognition of bronchoalveolar lavage-derived cytokines. J Allergy Clin Immunol 2008, 121:30-37.

35. Humbert M, Berger W, Rapatz G, Turk F: Add-on omalizumab improves day-to-day symptoms in inadequately controlled severe persistent allergic asthma. Allergy 2008, 63:592-596.

36. Takayama G, Arima K, Kanaji T, Toda S, Tanaka H, Shoji S, McKenzie AN, Nagai H, Hotokebuchi T, Izuhara K: Periostin: a novel component of subepithelial fibrosis of bronchial asthma downstream of IL-4 and IL-13 signals. J Allergy Clin Immunol 2006, 118:98-104.

37. Nair $P$, Pizzichini $M M$, Kjarsgaard $M$, Inman MD, Efthimiadis A, Pizzichini $E$, Hargreave FE, O'Byrne PM: Mepolizumab for prednisone-dependent asthma with sputum eosinophilia. N Engl J Med 2009, 360:985-993.

38. Kurowska-Stolarska M, Kewin P, Murphy G, Russo RC, Stolarski B, Garcia CC, Komai-Koma M, Pitman N, Li Y, Niedbala W, McKenzie AN, Teixeira MM, Liew FY, Xu D: IL-33 induces antigen-specific IL-5+ T cells and promotes allergic-induced airway inflammation independent of IL-4. J Immunol 2008, 181:4780-4790.

39. Prefontaine D, Nadigel J, Chouiali F, Audusseau S, Semlali A, Chakir J, Martin JG, Hamid Q: Increased IL-33 expression by epithelial cells in bronchial asthma. J Allergy Clin Immunol 2010, 125:752-754.

40. Agache I, Ciobanu C, Agache C, Anghel M: Increased serum IL-17 is an independent risk factor for severe asthma. Respir Med 2010, 104:1131-1137.

41. Bullens DM, Truyen E, Coteur L, Dilissen E, Hellings PW, Dupont L, Ceuppens JL: IL-17 mRNA in sputum of asthmatic patients: linking T cell driven inflammation and granulocytic influx? Respir Res 2006, 7:135.

42. Egerton M, Shortman K, Scollay R: The kinetics of immature murine thymocyte development in vivo. Int Immunol 1990, 2:501-507.

43. Wenzel S: Severe asthma: from characteristics to phenotypes to endotypes. Clin Exp Allergy 2012, 42:650-658.

44. Lai X, Li J, Xiao X, Liu E, Zhang C, Wang H, Gjesing B, Zhong N, Spangfort MD: Specific IgG4 production during house dust mite immunotherapy among age, gender and allergic disease populations. Int Arch Allergy Immunol 2013, 160:37-46.

45. Nakano K, Higashi T, Hashimoto K, Takagi R, Tanaka Y, Matsushita S: Antagonizing dopamine D1-like receptor inhibits Th17 cell differentiation: preventive and therapeutic effects on experimental autoimmune encephalomyelitis. Biochem Biophys Res Commun 2008, 373:286-291.

46. Okada $H$, Inoue $T$, Hashimoto $K$, Suzuki $H$, Matsushita S: D1-like receptor antagonist inhibits IL-17 expression and attenuates crescent formation in nephrotoxic serum nephritis. Am J Nephrol 2009, 30:274-279.

47. Nakano K, Yamaoka K, Hanami K, Saito K, Sasaguri Y, Yanagihara N, Tanaka S, Katsuki I, Matsushita S, Tanaka Y: Dopamine induces IL-6-dependent IL-17 production via D1-like receptor on CD4 naive T cells and D1-like receptor antagonist $\mathrm{SCH}-23390$ inhibits cartilage destruction in a human rheumatoid arthritis/SCID mouse chimera model. J Immunol 2011, 186:3745-3752.

48. Jaeschke R, O'Byrne PM, Mejza F, Nair P, Lesniak W, Brozek J, Thabane L, Cheng J, Schunemann HJ, Sears MR, Guyatt G: The safety of long-acting beta-agonists among patients with asthma using inhaled corticosteroids: systematic review and metaanalysis. Am J Respir Crit Care Med 2008, 178:1009-1016.
49. Sears MR, Ottosson A, Radner F, Suissa S: Long-acting beta-agonists: a review of formoterol safety data from asthma clinical trials. Eur Respir J 2009, 33:21-32.

50. de Vries F, Setakis E, Zhang B, van Staa TP: Long-acting $\beta 2$-agonists in adult asthma and the pattern of risk of death and severe asthma outcomes: a study using the GPRD. Eur Respir J 2010, 36:494-502.

51. Wijesinghe M, Weatherall M, Perrin K, Harwood M, Beasley R: Risk of mortality associated with formoterol: a systematic review and meta-analysis. Eur Respir J 2009, 34:803-811.

52. FDA Drug Safety Communication: New safety requirements for longacting inhaled asthma medications called Long-Acting Beta-Agonists (LABAs). In Drug Safety and Availability, Postmarket Drug Safety Information for Patients and Providers. Rockville, MD: US Food and Drug Administration; Available at http://www.fda.gov/Safety/MedWatch/Safetylnformation/ SafetyAlertsforHumanMedicalProducts/ucm201003.htm. Accessed on October 30, 2014.

doi:10.1186/s12865-014-0039-y

Cite this article as: Kato et al: $\beta 2$ adrenergic agonist attenuates house dust mite-induced allergic airway inflammation through dendritic cells. BMC Immunology 2014 15:39.

\section{Submit your next manuscript to BioMed Central and take full advantage of:}

- Convenient online submission

- Thorough peer review

- No space constraints or color figure charges

- Immediate publication on acceptance

- Inclusion in PubMed, CAS, Scopus and Google Scholar

- Research which is freely available for redistribution

Submit your manuscript at www.biomedcentral.com/submit
C Biomed Central 